\title{
Antenatal betamethasone administration before elective caesarean section in term pregnant women
}

\section{Miadında gebe kadınlarda elektif sezaryen öncesi antenatal betametazon uygulaması}

\author{
Begum Kurt ${ }^{1}$, Gülltekin Köse ${ }^{2}$
}

${ }^{1}$ Department of Obstetrics and Gynecology Clinic of Sivas Numune Hospital, Sivas, Turkey

${ }^{2}$ Department of Obstetrics and Gynecology Clinic of Haydarpaşa Numune Resarch and Training Hospital, İstanbul, Turkey

Corresponding author: Begum Kurt, MD, Department of Obstetrics and Gynecology Clinic of Sivas Numune Hospital, Sivas, Turkey

E-mail: dr.begumkurt@yahoo.com.tr

Received/Accepted: October 16, 2019 / December 31, 2019

Conflict of interest: There is not a conflict of interest.

\section{SUMMARY}

Objective: The aim of this study is to show that respiratory problems such as respiratory distressed syndrome and transient tachypnea of newborn can be reduced by antenatal betamethasone administration.

Method: The study was conducted on 50 mothers and their babies aged between 21 and 38 years in the Obstetrics and Gynecology Clinic of Haydarpaşa Numune Training and Research Hospital between January 2007 and March 2008. Betamethasone was administered to 25 patients who were planned for cesarean section at term due to elective reasons (Group I). The Group II consisted of 25 patients planned for elective caesarean section at term and no betamethasone was administered. Groups were compared according to maternal age, maternal smoking, maternal chronic disease history, gestation day, cesarean section type of anesthesia, birth weight and sex of the baby. Postnatal infants were evaluated according to Apgar scores of 1 and 5 minutes, ventilation with mask, intubation, resuscitation or intensive care needs. RDS and TNT were recorded.

Results: In the non-corticosteroid-treated group (group 2), two babies developed TNT of the newborn. However, no statistically significant difference was found between the groups ( $p>0.05)$. Respiratory distress syndrome did not develop in any of our patients. The abortion rate in Group I (20\%) was significantly higher than the abortion rate in Group II $(0 \%)(\mathrm{p}<0.05)$. No other parameters (Age, gravida, parity, number of curettage, number of living children, smoking,presence of chronic disease, anesthesia type) were statistically significant ( $\mathrm{p}>0.05)$.

Conclusions: The use of antenatal corticosteroid in elective caesarean sections over 37 weeks may cause a decrease in the development of respiratory problems such as RDS and YGT.

Keywords: Bethamethasone, corticosteroid, caesarean section.
Begum Kurt

(D) Gültekin Köse

ORCID IDs of the authors:

B.K. 0000-0002-7166-3130

G.K. 0000-0002-7894-8809

\section{ÖZET}


sezaryen planlanan 25 hastaya betametazon uygulandı (Grup I). Diğer 25 hastaya Betametazon uygulanmadı (Grup II), Gruplar maternal yaş, maternal sigara içimi, maternal kronik hastalık öyküsü, gebelik günü, sezaryen anestezi tipi, doğum ağırlığı ve bebeğin cinsiyeti açısından karşılaştırıldı. Doğum sonrası bebekler Apgar skorları 1 ve 5 dakikalık, maskeli ventilasyon, entübasyon, resüsitasyon veya yoğun bakım gereksinimlerine göre değerlendirildi. RDS ve TNT kaydedildi.

Bulgular: Kortikosteroid tedavisi görmemiş grupta (grup 2) iki bebekte yenidoğan TNT gelişti. Ancak, gruplar arasında istatistiksel olarak anlamlı bir fark bulunmadı ( $>0.05$ ). Hiçbir hastamızda solunum sıkıntısı sendromu gelişmedi. Grup I'deki abortus oranı (\% 20) Grup II'deki abortus oranından anlamlı derecede yüksekti $(\% 0)(\mathrm{p}<0,05)$. Diğer parametreler (Yaş, gravida, parite, küretaj sayısı, yaşayan çocuk sayısı, sigara içme, kronik hastalık varlığı, anestezi tipi) istatistiksel olarak anlamlı değildi ( $\mathrm{p}>0.05)$.

Sonuç: Antenatal kortikosteroidin 37 haftanın üzeri gebelerde, elektif sezaryenlerde kullanılması, RDS ve YGT gibi solunum problemlerinin gelişiminde azalmaya neden olabilir.

Anahtar sözcükler: Betametason, kortikosteroid, elektif sezeryan.

\section{INTRODUCTION}

Cesarean delivery is increasing in our country as in the whole world. The most important reason for this increase is that patients have social indications (favorable time adjustment, fear of birth, precious baby) rather than medical indications. $^{1}$

According to the data of the Ministry of Health, the rate of cesarean section in all deliveries in our country between 1998-2003 was 21.2 percent, and in 2016 it was found to be 53.1 percent.

Respiratory distress syndrome (RDS) of the newborn is a problem of pulmonary maturation at birth due to endogenous surfactant deficiency in the lungs. The surfactant reduces surface tension in the area of air contact with the alveolar surface and thus prevents the alveoli from collapsing during expiration. The frequency of RDS is inversely proportional to the gestational week.

Benign respiratory distress, type II respiratory distress also known as transient tachypnea, is one of the main causes of respiratory distress in newborns. The reason of transient neonatal tachypnea (TNT) is thought to be due to insufficient fetal lung fluid. The presence of tachypnea in the first hours after delivery, lack of septic appearance in the patient, normal laboratory findings to assist sepsis, increased aeration on the chest X-ray, flattening of the diaphragm, an increase in bronchovascular appearance, the presence of fluid appearance in the fissures and pleura and the response to treatment with oxygen below $40 \%$ in a short time is diagnostic. ${ }^{2,3}$

Respiratory distress develops in approximately $1 \%$ of newborns. $33-50 \%$ of them consist of TNT and RDS ${ }^{4}$. It is known that labor increases vaginal steroid synthesis in vaginal births and accelerates the synthesis of surfactant in the lung in infants. The absence of labor in elective cesarean section is one of the reasons that RDS and TNT are more common in babies born by cesarean section.

Respiratory distress syndrome (RDS) and TNT in term pregnant women are more common in cesarean delivery than vaginal delivery ${ }^{5}$. Other causes of these two clinical conditions are gestational age, fetal asphyxia, maternal diabetes, asthma, and type of anesthesia used at birth ${ }^{5-8}$. The development of RDS and TNT often requires the follow-up of newborn infants in neonatal intensive care units. In the literature, routine application of corticosteroids is recommended for births before 34 weeks. 9,10 Antenatal corticosteroids have been used for many years in pregnancies that threaten preterm birth between 24-34 weeks. It was shown that the decrease in the development of respiratory problems such as RDS and TNT when used before cesarean in pregnancies above 37 th week. ${ }^{11}$ Corticosteroids have been shown to reduce RDS and TNT as well as mortality and morbidity. At the same time, it was found that they did not cause any side effects in infants in early childhood. ${ }^{12-15}$

In this study, we aimed to investigate the effects of antenatal corticosteroids in the development of respiratory problems such as RDS and TNT in elective caesarean sections over 37 weeks.

\section{MATERIAL AND METHODS}

This study was conducted between January 2007 and March 2008 in Obstetrics and Gynecology Clinic of Haydarpaşa Numune Research Hospital. A total of 50 mothers and their infants aged between 21 and 38 years were enrolled. The study was approved by the local ethics committee of Haydarpaşa Numune Training and Research Hospital ( protochol no: 07-01).

Betamethasone was administered to 25 patients who were scheduled for cesarean section due to elective reasons (Group I). A total of $12 \mathrm{mg}$ betametazon (Celestone Chronodose, IV form, 
Full composition: $3,947 \mathrm{mg}$ betamethasone disodium phosphate and $3 \mathrm{mg}$ betamethasone acetate) intramuscular injection; 2 dosage in the morning and 2 dosage in the evening, was administered. The Group II consisted of 25 patients scheduled for elective caesarean section at term and no betamethasone was administered.

Groups were compared according to maternal age, maternal smoking, maternal chronic disease history, gestation day, cesarean section type of anesthesia, birth weight and sex of the baby.

Postnatal infants were evaluated according to Apgar scores of 1 and 5 minutes, ventilation with mask, intubation, resuscitation or intensive care needs. RDS and TNT were recorded.

This is a prospective and randomized study. Randomization was done by using closed envelope method. Betamethasone $6 \mathrm{mg}, 2 * 2$ was administered to the patients once. At least 24 hours after the last dose, caesarean was performed.

\section{Exclusion criteria}

In 24 hours after antenatal betamethasone administration, the patients who had to be taken by cesarean section for urgent reasons before the efficacy of the drug was formed and the patients with side effects due to corticosteroids. These patients were not included in the study.

\section{Statical analysis}

Statistical evaluation of the findings was performed with SPSS (Windows 15.0) program. Descriptive statistical methods (mean, standard deviation, frequency) as well as the quantitative data were compared with Student's $t$ test. The chisquare test and Fisher's Exact chi-square test were used to compare the qualitative data. The results were evaluated with $95 \%$ confidence interval and $\mathrm{p}<0.05$ significance level.

\section{RESULTS}

The study was conducted on 50 mothers and their babies aged between 21 and 38 years in the Obstetrics and Gynecology Clinic of Haydarpaşa
Numune Training and Research Hospital between January 2007 and March 2008. The mean age of the mothers was $28.1 \pm 4.6$ years. In the study, the patients receiving betamethasone were determined as Group I and the patients who were not receiving the drug were Group II.

While $20 \%$ of the mothers participated in the study were between 20-24 years old, $48 \%$ were between 25-29 years old, 22\% were between 30 34 years old and $10 \%$ were 35 years and older. While $16 \%$ of the cases had 1 gravida, $54 \%$ had 2 , $30 \%$ had 3 and above. While $30 \%$ of the cases had no parity, $52 \%$ had 1 parity, $18 \%$ had 2 parity or more. Abortion was seen in $10 \%$ of the cases. $15 \%$ of the patients had curettage. While $32 \%$ of the cases had no living children, $52 \%$ had $1,16 \%$ had 2 or more children. $20 \%$ of the cases were smokers. $20 \%$ of cases have chronic disease (Two patients had epilepsy, four patients had thyroid disease, two patients had asthma, two patients had rheumatic disease). While $80 \%$ of the patients had general anesthesia, 20\% had spinal anesthesia (Table 1).

The abortion rate in Group I (20\%) was significantly higher than the abortion rate in Group II $(0 \%)(p<0.05)$. No other parameters (Age, gravida, parity, number of curettage, number of living children, smoking, presence of chronic disease, anesthesia type) were statistically significant ( $>00.05)$, (Table 1).

The birth weight of the babies varies between $2430 \mathrm{~g}$ and $4340 \mathrm{~g}$; the average is $3425.4 \pm 398.8$ gr. $46 \%$ of the babies are girls and $54 \%$ are boys. The first minute Apgar scores of the babies ranged from 4 to 9; The mean 1st minute Apgar score was $7.7 \pm 0.9$. The 5 th minute Apgar scores of the babies ranged from 7 to 10 ; The mean 5 th minute Apgar score was $9.5 \pm 0.7$. There was no statistically significant difference between the groups in terms of birth weight, gender, Apgar score of $1 \mathrm{~min}$ and Apgar score of $5 \mathrm{~min}$. Only 2 babies (4\%) had TNT in group II, but this parameter was not statiscally singificant too. No RDS developed in both groups (Table 2). 
Table 1: Evaluation of Maternal Characteristics by Groups

\begin{tabular}{|c|c|c|c|c|}
\hline & & $\begin{array}{c}\text { Group I }(\mathrm{n}=25) \\
\mathrm{n}(\%)\end{array}$ & $\begin{array}{c}\text { Group II }(\mathrm{n}=25) \\
\mathrm{n}(\%)\end{array}$ & $\mathrm{p}$ \\
\hline \multirow{4}{*}{ Age } & $20-24$ & $5(20 \%)$ & $5(20 \%)$ & \multirow{4}{*}{0.465} \\
\hline & $25-29$ & $14(56 \%)$ & $10(40 \%)$ & \\
\hline & $30-34$ & $5(20 \%)$ & $6(24 \%)$ & \\
\hline & 35 and over & $1(4 \%)$ & $4(16 \%)$ & \\
\hline \multirow{3}{*}{ Gravity } & 1 & $2(8 \%)$ & $6(24 \%)$ & \multirow{3}{*}{0.157} \\
\hline & 2 & $13(52 \%)$ & $14(56 \%)$ & \\
\hline & 3 and over & $10(40 \%)$ & $5(20 \%)$ & \\
\hline \multirow{3}{*}{ Parity } & None & $5(20 \%)$ & $10(40 \%)$ & \multirow{3}{*}{0.244} \\
\hline & 1 & $14(56 \%)$ & $12(48 \%)$ & \\
\hline & 2 and over & $6(24 \%)$ & $3(12 \%)$ & \\
\hline \multirow[t]{2}{*}{ Abortus } & + & $5(20 \%)$ & $\mathbf{0}$ & \multirow[t]{2}{*}{$0.05^{*}$} \\
\hline & - & $20(80 \%)$ & $25(100 \%)$ & \\
\hline \multirow[t]{2}{*}{ Currettage } & + & $7(28 \%)$ & $8(32 \%)$ & \multirow[t]{2}{*}{0.758} \\
\hline & - & $18(72 \%)$ & $17(68 \%)$ & \\
\hline \multirow{3}{*}{$\begin{array}{l}\text { Number of children } \\
\text { living }\end{array}$} & None & $6(24 \%)$ & $10(40 \%)$ & \multirow{3}{*}{0.437} \\
\hline & 1 & $14(56 \%)$ & $12(48 \%)$ & \\
\hline & 2 and over & $5(20 \%)$ & $3(12 \%)$ & \\
\hline \multirow[t]{2}{*}{ Smoking } & + & $4(16 \%)$ & $6(24 \%)$ & \multirow[t]{2}{*}{0.480} \\
\hline & - & $21(84 \%)$ & $19(76 \%)$ & \\
\hline \multirow[t]{2}{*}{ Chronic disease } & + & $5(20 \%)$ & $5(20 \%)$ & \multirow[t]{2}{*}{1,000} \\
\hline & - & $20(80 \%)$ & $20(80 \%)$ & \\
\hline \multirow[t]{2}{*}{ Anesthesia type } & General & $19(76 \%)$ & $21(84 \%)$ & \multirow[t]{2}{*}{0.480} \\
\hline & Spinal & $6(24 \%)$ & $4(\% 16)$ & \\
\hline
\end{tabular}

Table 2: Evaluation of the groups according to the characteristics of the babies

\begin{tabular}{|c|c|c|c|c|}
\hline & & $\begin{array}{c}\text { Group I }(n=25) \\
\text { Mean value } \pm \text { SD }\end{array}$ & $\begin{array}{l}\text { Group II }(n=25) \\
\text { Mean value } \pm \text { SD }\end{array}$ & $\mathbf{p}$ \\
\hline Birth weight(gr) & & $3361,6 \pm 386,8$ & $3489,2 \pm 408$ & 0,262 \\
\hline $\begin{array}{l}\text { 1. minute Apgar } \\
\text { score }\end{array}$ & & $7,6 \pm 0,9$ & $7,7 \pm 0,9$ & 0,631 \\
\hline $\begin{array}{l}\text { 5.minute Apgar } \\
\text { score }\end{array}$ & & $9,4 \pm 0,6$ & $9,6 \pm 0,8$ & 0,409 \\
\hline \multirow[t]{2}{*}{ Sex } & Girl & $14(56 \%)$ & $9(36 \%)$ & \multirow[t]{2}{*}{0,156} \\
\hline & Boy & $11(44 \%)$ & $16(64 \%)$ & \\
\hline \multirow{2}{*}{$\begin{array}{l}\text { Transient neonatal } \\
\text { tachypnea (TNT) }\end{array}$} & + & $\mathbf{0}$ & $2(8 \%)$ & \multirow[t]{2}{*}{0.490} \\
\hline & - & $25(100 \%)$ & $23(92 \%)$ & \\
\hline
\end{tabular}




\section{DISCUSSION}

While caesarean section was performed at $5 \%$ in all births in 1960s, the rate of application gradually increased after these years and increased to $25-30 \%$ in $1980 \mathrm{~s}$. Today, in most developed countries, $15-25 \%$ of all deliveries are performed by cesarean section. ${ }^{16}$

Women getting married at a later age than before, getting pregnant at a later age, wanting to have fewer children, presence of infertility problems, infertile women becoming pregnant with treatment, introducing concepts such as 'Risky pregnancy', 'Precious baby', is the factors that increase cesarean rates. In addition, the birth of sequelae children who may be due to birth trauma causes serious legal problems between families and physicians.

Cesarean section was applied in all pregnancies of pregnant women who had cesarean section once.Birth maneuvers are less applied, vaginal delivery has been rarely used in breech delivery. Nowadays, the importance of antenatal prophylaxis can be understood more clearly considering the increasing rates of cesarean delivery.

In our study, when antenatal corticosteroid administration was used in elective cesarean sections over 37 weeks, such as RDS and TNT. We thought that it may cause a decrease in the development of respiratory problems and thus affect mortality and morbidity.

Premature and respiratory problems are the most common causes of mortality and morbidity in newborns. In the literature, routine use of corticosteroids is recommended for delivery before 34 weeks of gestation ${ }^{9-10}$. It was found that corticosteroids decreased RDS and TNT, but also mortality and morbidity and did not cause any side effects in infants in early childhood ${ }^{17}$. Many studies have shown that the effect of prenatal betamethasone or dexamethasone to prevent RDS is at the 26th gestational week at the earliest and can be used until the 36th gestational week $(2,4)$. The NIH (National Institute of Health) consensus proposed steroid treatment for all fetuses between 24-34 weeks of gestation at risk of premature birth, according to a 1994 report. ${ }^{18}$

Increased risk of maternal infection due to corticosteroid use and changes in immunological response have been reported in some publications. In prospective randomized studies of Morales et al. and Gamsu et al., There was no increase in maternal infection or neonatal sepsis with betamethasone use. ${ }^{19,20}$
Routine deliveries in the literature before the 34 th gestational week corticosteroids have been recommended. ${ }^{9,10}$ However, there is no clear consensus on the use of corticosteroids before elective cesarean section in term pregnant women.

Stutchfield et al. ${ }^{11}$ were conducted in the UK (Antenatal Steroids for Term Elective Caesarean Section (ASTECS)) and compared prophylactic administration of betamethasone (12 mg x 2, 24 hours apart intramuscular, $\mathrm{N}=467$ women) versus usual treatment without antenatal corticosteroids ( $\mathrm{N}=475$ women $)$ in women undergoing term elective caesarean section. Women randomised to the treatment group received two intramuscular doses of betamethasone in the 48 hours before delivery, whereas the control group received treatment as usual. Similiar studies (Ahmed et.al, Nada et.al, Nooh et.al), ${ }^{21-23}$ compared prophylactic administration of dexamethasone with placebo or standard care. The Ahmed trial ${ }^{21}$ randomised women undergoing elective caesarean section from $37+0$ to $39+6$ weeks to either dexamethasone $(12 \mathrm{mg} \times \mathrm{x} 2,24$ hours apart intramuscular, $\mathrm{n}=228$ ) at 37 weeks, or standard care without antenatal corticosteroids $(\mathrm{n}=224)$. The Nada trial $^{22}$ randomised women undergoing elective caesarean section between $38+0$ and 38 +6 weeks to either dexamethasone $(8 \mathrm{mg} \mathrm{x} 4,12$ hours apart intramuscular, $\mathrm{n}=645$ ) or placebo (normal saline intramuscular, $\mathrm{n}=645$ ) 48 hours prior to the operation. The Nooh $\operatorname{trial}^{23}$ randomised women undergoing planned caesarean section at 38 weeks gestation or beyond to either dexamethasone $8 \mathrm{mg}$ three times at eight hours apart intramuscular, $\mathrm{n}=636$ ) 24 hours prior to the operation, whereas the control group $(n=636)$ received treatment as usual. The overall observed rate of RDS and TNT in the control group was $1.7 \%$ and $5.4 \%$, respectively, in the included studies. ${ }^{11,21-23}$ Approximately $3.4 \%$ of neonates in the control group were admitted to the neonatal intensive care unit because of respiratory symptoms. Evidence from four randomised controlled trials suggests that prophylactic corticosteroids before elective caesarean section at term may reduce the rates of respiratory distress syndrome (RDS), TNT and admission to neonatal intensive care unit for respiratory morbidity. In this study, postnatal TNT was observed in 2 babies in the group who did not use corticosteroids before elective cesarean section in term pregnant women. Although not statistically significant, the reason was attributed to the low number of patients in the study groups. RDS was not observed in both groups. 
Multicentre studies are needed with more patients with corticosteroid administration in elective cesarean section. Nowadays, the increase in maternal mortality and morbidity should be taken into consideration in the face of increasing cesarean rates.

\section{REFERENCES}

1. Cotzias CS, Paterson-Brown S, Fisk NM. Obstetricians say yes to maternal request for elective caesarean section: a survey of current opinion. Eur J Obstet Gynaecol Reprod Biol 2001; 97: 15-6.

2. Hansen T, Corbet A. Disorders of the transition. In: Taeusch HW, Ballard RA (eds): Avery's diseases of newborn. 7 th edition. Philadelphia: WB Saunders Company;1998. 613-5.

3. Ovalı F. Yenidoğanın geçici taşipnesi. Dağoğlu T (ed). Neonatoloji. İstanbul: Nobel Tip Kitabevi; 2000. 297-8.

4. Tricia Lacy Gomella. Respiratory Distres Syndrome. Neonatology 1999; 503-4.

5. Morrison JJ, Rennie JM, Milton PJ. Neonatal respiratory morbidity and mode of delivery at term: influence of timing of elective caesarean section. Br J Obstet Gynaecol 1995;102:101-6.

6. Schatz M, Zeiger RS, Hoffman CP, Saunders BS, Harden KM, Forsythe AB. Increased transient tachypnoea of the newborn in infants of asthmatic mothers. Am J Dis Child 1991;145:156-8.

7. Demissie K, Marcella SW, Breckenridge MB, Rhoads GG. Maternal asthma and transient tachypnoea of the newborn. Pediatrics 1998; 102: 84-90. 10 Crowley P. Prophylactic corticosteriods for preterm birth. Cochrane Database Syst Rev 2000;(2):CD000065.

8. Robert ME, Neff RK, Hubbell JP, Taeusch HW, Avery ME. Association between maternal diabetes and the respiratory distress syndrome in the newborn. N Engl J Med 1976; 294: 357 60.

9. Royal College of Obstetricians and Gynaecologists Scientific Advisory Committee. RCOG guidelines No 7: antenatal corticosteroids to prevent respiratory distress syndrome. 2nd ed. London: RCOG Press, 2004:1-9.

10. Crowley P, Chalmers I, Keirse MJNC. The effects of corticosteroid administration before preterm delivery: an overview of the evidence from controlled trials. Br J Obstet Gynaecol 1990; 97: 1125.

11. Stutchfield P, Whitaker R, Russell I, Antenatal Steroids for Term Elective Caesarean Section (ASTECS) Research Team. Antenatal betamethasone and incidence of neonatal respiratory distress after elective caesarean section: pragmatic randomised trial. BMJ 2005; 331(7518): 662.

12. Creasy RK, Iams JD. Preterm labor and delivery. In: Creasy RK, Resnik R (eds). Maternal Fetal Medicine (4th ed). Philadelphia: WB Saunders, 2000: 498509.

13. Collaborative group on antenatal steroid therapy. Effect of antenatal dexamethasone administration on the prevention of respiratory distress syndrome. Am J Obstet Gynecol 1981; 141: 276-87.

14. NIH Consensus Development Conference Statement. Effect of corticosteroids for fetal maturation on perinatal outcomes. JAMA 1995; 273: 413-18.

15. Cosmi EV, Anceschi MM. Prevention of fetal and neonatal lung immaturity. In: Textbook of Perinatal Medicine (1st ed). Carnforth: The Parthenon Publishing Group Ltd, 1998: 1382-92.

16. Lagrew DC Jr, Morgan MA. Decreasing the cesarean section rate in a private hospital : success without mandated clinical changes . Am J Obstet Gynecol 1996; 174: 184-91

17. Kay HH, Bird IM. Kay HH, Bird IM, Coe CL, Dudley DJ. Antenatal steroid treatment and adverse fetal effects: what is the evidence? J Soc Gynecol Investig 2000; 7: 269-78.

18. NIH Consensus Development Conference Statement. Effect of corticosteroids for fetal maturation on perinatal outcomes. JAMA 1995; 273: 413-18.

19. Morales WJ, Diebel ND, Lazar AJ, Zadrozny D. The effect of antenatal dexamethasone administration on the gestations with premature rupture of membranes. Am J Obstet Gynecol 1986; 154: 591-95.

20. Gamsu HR, Mullinger BM, Donnai P, Dash $\mathrm{CH}$. Antenatal administration of betamethasone to prevent respiratory distress syndrome in preterm infants: report of a UK multicentre trial. $\mathrm{Br} \mathrm{J}$ Obstet Gynaecol 1989; 96: 401-10. 
21. Ahmed MR, Ahmed WAS, Mohammed TY. Antenatal steroids at 37 weeks, does it reduce neonatal respiratory morbidity? A randomized trial. Journal of MaternalFetal \& Neonatal Medicine 2015;28(12):1486-90.

22. Nada AM, Shafeek MM, El Maraghy MA, Nageeb AH, Salaheldine AS, Awad MH. Antenatal corticosteroid administration before elective caesarean section et term to prevent neonatal respiratory morbidity: a randomized controlled trial. European Journal of
Obstetrics, Gynecology, and Reproductive Biology 2016; 199: 88-91.

23. Nooh AM, Abdeldayem HM, Arafa E, Shazly SA, Elsayed H, Mokhtar WA. Does implementing a regime of dexamethasone before planned cesarean section at term reduce admission with respiratory morbidity to neonatal intensive care unit? A randomized controlled trial. Journal of Maternal-Fetal \& Neonatal Medicine 2018; 31(5): 61420. 